UDC 808:8123

Lilit BRUTIAN

\title{
COMPLIMENT TO A COMPLIMENT: AN ANALYSIS OF THE SPEECH ACT OF A COMPLIMENT
}

\author{
Dedicated to my father \\ Academician Georg Brutian
}

\begin{abstract}
In the paper, an attempt is made to thoroughly analyse the speech act of a compliment as a rhetorical device. In particular, the value of compliments from the viewpoint of effective communication, as well as the motives of compliment making and accepting/non-accepting are being considered. In addition, the speech act of a compliment is analysed in the light of gender and intercultural similarities and differences. It is shown that with all the similarities in the functioning of the speech act of a compliment, there are essential differences that reflect the peculiarities in the mentality of the language bearers.
\end{abstract}

Keywords: speech act of a compliment, rhetorical, impact, effective communication, gender, intercultural.

Today, as a result of intensification of contacts of various kinds the study of both interpersonal and intercultural communication which aims at minimization of communication failures and the achievement of effective and harmonious communication has been in the focus of keen interest of linguists, psychologists, philosophers, specialists in communication and in related disciplines, because of its urgency and importance.

In the framework of modern anthropocentric scientific paradigm the theory of speech acts as an integral part of the theory of communication, which is based on the ideas of outstanding philosophers of language Grice, Searle, Austin and others, occupies its own, very important niche. The object of our investigation is the speech act of a compliment, one of the types of speech acts which has been analysed little so for. Our goal is to analyse the given speech act thoroughly, from different aspects and in the light of modern theories and research tendencies, in particular, pragmalinguistics, gender linguistics, theory of communication, etc. The following questions will be analysed in the paper: the impact of a compliment, the reasons for compliment making/not making and accepting/non-accepting, compliments in the light of gender differences, compliments in the context of intercultural communication.

As A.P. Sadokhin correctly mentions, "it has been ascertained that the character, form and the style of communication depend to a 
great extent on the first minutes, sometimes seconds of communication. There exist a lot of very simple devices that allow practically in every situation to make the initial stage of communication easier, which determines the entire further course of this process. Among such devices is a compliment" (Sadokhin, 2010, p. 139).

There are different types of compliments: sincere and flattering, effective and ambiguous, appropriate and inappropriate, etc. In rhetoric there are several requirements to compliments. In this connection I. Gorelov and K. Sedov write: "Compliment is a "small form" of epideictic eloquence which goes back to the speech culture of Middle Ages, to the tradition of extolment by the knight of his beautiful lady. ...Compliment requires realized speech efforts from the speaker, it presupposes artistic and creative orientation in speech. It goes without saying that different language personalities follow different speech strategies in creating a compliment, and the choice of these strategies is determined by the types of individual styles of the speakers. Yet, as the observations of every-day discourse have shown, ... in the choice of intragenre strategies the type of the language personality of the speech addressee plays a great role. It is not by chance that the main rhetoric recommendation in this genre is the orientation on "loving attention to the addressee and polish". Indeed, compliment arises from the wish to please the speaker. And to evoke positive emotions in a man, one must know his individual features, including the peculiarities of his language personality. That is why the main rhetorical requirement to a compliment is harmony (compliment is made differently to different people depending on their age, degree of closeness with them of the speaker, etc.) and the right situation (in some cases the appearance can be praised, in some other the intellect, etc.) Besides, a compliment must be sincere and non-trivial, which corresponds to the rules of cooperative communication" (Gorelov \& Sedov, 2005, pp. 180-181).

There are different reasons of making compliments. It is, first of all, a good means "to achieve the affection of the addressee and to establish the foundations of long-lasting and effective communication" (Sadokhin, 2010, p. 139). Compliments are made also because of courtesy. On the other hand, often compliments are made to receive a compliment in return: "You scratch my back and I'll scratch yours". In connection with the twoway character of a compliment F. Laroshfuko said: "As a rule, we praise other people just to hear words of praise addressed to ourselves". There are also other reasons: "We sometimes extol the valour of one person to humiliate another person (Laroshfuko, 1990). Finally, among the intentions of compliment making flattery and personal advantage can be singled out.

From the point of view of the impact on the addressee and the value of words of compliments in general, it is worth mentioning that, first of all, compliments satisfy the most important psychological need of a person the need of positive emotions and have also educational importance. Besides, the ability to notice positive qualities in other people helps us to reveal good features in ourselves (Soon//http://lifecouachesblog.com). Victor Hugo has compared words of praise with a kiss through veil. Hence, the value of complimenting is also in giving pleasure to each other. 
Thus, the value of complimenting as a verbal activity is in that it lays the foundation of effective communication, establishes good relations with the addressee, influences him in the favour of the addresser, puts in the right mood, has educational importance, raises the estimation and self-estimation of both the addresser and the addressee.

Let us consider now the reactions to compliments. Although the majority of people likes to receive compliments, their perception and replies to them are different determined by various factors, including intercultural differences. On the whole, compliments are received with pleasure, as each person is delighted by the fact that the speaker wishes to say something nice to him, and the possible slips can be easily excused. Yet, there are cases when the compliment is being received in the opposite meaning (with the sign “_“). Thus, for example, quite an opposite meaning can attach to the words of a compliment a specific smile accompanying theses words, which transforms them to mockery. Or other associations, negative emotions can arouse in the addressee the ambiguous or flattering compliments. The replies, such as "It is only a compliment", "You are flattering me" and the like come to prove that the words of a compliment do not reflect the reality and are just flattering. Another case when the compliment is not being accepted, can be perceived wrongly and interpreted as flattery is the case when the addressee and the addresser are in the relations of "chief and subordinate". That is the reason why often subordinates avoid making compliments to their chiefs. Sometimes compliments are not being accepted by the listener who has the intention to hear it again. This tactics of compliment rejecting can be considered as an indirect fishing for a compliment. In F. Laroshfuko's words, "Evading praise is a request to repeat it" (Laroshfuko, 1990).

Thus, the speech act of a compliment is on of the types of speech acts which, in its turn, consists of complimenting words and expressions of various character, different tactics of accepting/non-accepting a compliment by the addressee and is characterized by variety of intentions and motives of compliment making (expression of courtesy, raise of estimation and self-estimation, the wish to please the addressee or even to insult him, personal advantage, etc.).

Of interest is also the study of compliments in the aspect of gender differences. It is believed that compliments must be addressed only to women, that by means of two or three trivial compliments her vanity can be flattered, that men do not like compliments. In fact, it is fallacy. In reality, as observations, as well as various investigations of researchers in the field of psychology of communication show, both women and men like to hear compliments. And the false opinion that men do not like compliments can be explained, first, by the fact that they, being more reserved, hide their reaction (in fact, positive, if it is not flattery), whereas women, being more emotional than men, do not hide their emotions, their satisfaction and joy when getting compliments and are always open to them: it is known that women love by hearing, they strongly need "verbal strokes" (N. Formanovskaya's term). It should be added that the difference in the attitude to a compliment on the part of two sexes is in that women are never tired of compliments, they want to always hear them to keep up their self-esteem and 
self-confidence. On the other hand, in many cultures it is typical for men to make compliments to women and not vice versa: males, being "strong sex", allow themselves to "favour women with attention" and say pleasant words determined by their higher status. There is one more factor: compliments concerning appeareance are addressed mainly to women but not men, and there are many things to praise (the new dress, the hair-do and so on and so forth). Finally, in spite of gender discrimination the woman has always been an object of worship, admiration, reverence and the muse for men. In V.G. Gak's words, "it is common knowledge that the best words in the world have been addressed to the women or said about women..." (Gak, 2003, p. 598). All the abovesaid speaks to the inequality of distribution of compliments among men and women: women receive them more often though men like to get as much.

Let us now consider the speech act of a compliment in the light of intercultural differences and similarities: with all the commonality of one and the same orientation - to please the addresser - the form of the expression, as well as the perception and interpretation of a compliment often differ to a great extent in different cultures. This is determined by the mentality of the bearers of this or that culture, the sex and age of the communicators, by the difference in the norms of expressing emotions, in particular, the feeling of liking. There are also essential differences in the reactions to compliments in different cultures, sometimes even in close ones. That is the reason why one and the same expression used as praise, admiration, approval in one society can be perceived in another one as flattery, and even as insult.
Thus, for example, in English-speaking cultures "they encourage to praise people to raise them in their own eyes. On the contrary, in the Japanese culture they do not encourage to praise in somebody's face, but they approve to speak "badly" about themselves" (Wierzbicka, 1997, pp. 397-398). The Japanese who are restrained in praise and compliments (and who, at the same time have a special form of gratitude in reply to the words of praise) interpret the direct compliments made by Americans as flattery but not expression of sincere praise.

It is known that in the USA to make a compliment to a woman during work hours (to praise her appearance, her clothes, etc.) can be interpreted as sexual harassment which can lead to imprisonment and heavy fines (by the way, many American feminists have used this opportunity). In the USA complimenting a women can, indeed, be sometimes very dangerous, whereas in Italy where there is a general cult of beauty, "it is common to admire a woman and to express this admiration. A feature that characterizes Italian men positively is that they admire and, most importantly, demonstrate their admiration to each woman, with no exception: ugly, old, young, silly, beautiful.... Even if it is a game, it is a game that is pleasant deep in the heart to the most awful feminists" (Pavlovskaya, 2006, pp. 234-235). In the moslim countries, on the contrary, it is forbidden to make compliments on the appearance of the addressee's wife, even though in the countries of Arab world it is common thing to shower praises on each other.

Though, as it has already been mentioned, women, generally speaking, like to receive compliments very much, in this, too, 
there are intercultural differences. Here is an example of how the women of Scandinavia, which is considered to be "the bulwark of victorious feminism", react to compliments: "The $8^{\text {th }}$ of March, as usual, was marked by the battle for women's rights. Many Scandinavian women reject on the "Women's Day" flowers, compliments, small presents and other manifestations of gallantry typical for other countries, as they see in them a hidden attempt to return to the patriarchal structure of a society where "the weak sex" is subordinate to males" ("Novoe vremya", 2010).

Frank Miller, Professor of Colombia University in New York, who teaches there Russian and who has a rich experience of communicating with the Russian people, describes in one of his interviews the difference in reactions to compliments determined by different cultural traditions: "The Americans will gladly accept a compliment with words of gratitude, while the Russians will by no means reject it, saying: "Not a bit of it!" ("Oh, come!") or "Knock a wood" ("Russkii yazyk za rubezhom", 2011).

It is worth mentioning that in many linguo-cultures comparisons with animals are used as compliments, and often what is used as a compliment in one culture can not be accepted as such and even be perceived as insult. Thus, in the Russian culture, "птичка, рыбонька, сокол, орленок" (birdie, little fish, falcon, eaglet) are all terms of affection or praise" (Feller, 1964, p. 59). In I. Gorelov and K. Sedov's words, "very curious impression on bearers of other cultures can leave some compliments to women. In India people can flatter a woman comparing her with a cow and the way of her walking with that of elephant's. A good compliment to a Japanese woman is the comparison with a snake, to a Tatar and Bashkir woman with a leech which is an embodiment of the perfection of forms and movement. Addressing a woman by means of the word "Гусыня" (goose) is insulting in the Russian culture. In Egypt it is a gentle compliment" (Gorelov \& Sedov, 2005, p. 132). In Armenia a compliment to a male is a comparison with a lion, with an eagle; a little child can be gently called a lamb, and a compliment to a woman is comparing her with a fallow-deer.

Let us consider compliments in the Armenian culture more in detail. The Armenians are in a sense a nation of extremes. On the one hand, during different festive occasions and especially during the unique female holiday which lasts for a whole month in Armenia a woman can hear praises and lots of compliments. On the other hand, in every-day life people are reluctant to make compliments to each other which is the result of difficulties of life, as well as our mentality. The famous Armenian actor and public figure Sos Sarkissian in one of his interviews once said: "A saving lie is a powerful thing. It is possible to make a compliment even to an ugly woman, to make her happy. My people have political... truth" (“Komsomol'skaya pravda", 2009).

And how do we receive compliments, if they are good, sincere ones? The observations show that the Armenians, especially the Armenian women are in the habit of rejecting them with words: "No, it is not so", "Just the opposite", etc. Such reactions reflect our mentality: the lack of confidence in the speaker, the orientation towards seeing some trick or flattery, some implicit, hidden meaning, as well as our certain restriction, the lack of experience in getting compliments. It should be 
stressed that this concerns to a great extent middle-aged and senior women. Today's young Armenian women and girls accept compliments with great dignity and words of gratitude under the influence of globalization and widely spread Americanization.

Aiming at a deeper analysis of the speech act of a compliment in Russian, Armenian and English linguo-cultures, we have analysed the corresponding dictionary articles, phraseological units, word combinations, proverbs and sayings, as well as patterns of complimenting discourses in the mentioned languages. The comparative analysis has led us to the following conclusions: 1) from the viewpoint of axiological characteristics compliments have the most positive colouring in the English linguo-culture whereas the most negative and subjective one in the Armenian culture. In the Russian language consciousness compliment has, alongside with positive connotations which prevail, also negative connotations connected with the overevaluation of the addressee and mercenary intentions of the addresser; 2) in the English culture as compared with Russian and Armenian compliments have a more formal character; 3 ) in the Russian and Armenian language consciousness, unlike the English one compliments are connected with the intention of the speaker aiming at personal advantage; 4) in the English mentality compliment is associated first of all with approval, which lacks in the Armenian culture; 5) in the English and Russian linguo-cultures, as distinct from the Armenian one, compliment is associated with the notions of politeness and respect; 6) in the Armenian linguo-culture, unlike Russian and English, compliment is a groundless praise; 7) compliment as sympathy and wider - em- pathy is met only in the Russian linguoculture; compliment understood in this meaning is a purely Russian phenomenon; 8) compliments in the Russian and especially Armenian cultures, unlike the English one, are accepted with difficulty.

To sum up all the above-said, it can be concluded that with all the similarities in the functioning of the speech act of a compliment in different linguo-cultures, there exist essential differences that reflect the peculiarities in the mentality of the language bearers.

\section{REFERENCES}

"Komsomol'skaya pravda" ("Komsomol truth", in Russian). (2009). N50.

"Novoe vremya" ("The New Times", in Russian). (2010). March 11.

"Russkii yazyk za rubezhom" ("Russian Language Abroad", in Russian). (2011). N3.

Feller, M. (1964). Kak rozhdayutsya i zhivut slova (How words are born and live, in Russian). Moscow: Prosveshhenie.

Gak, V.G. (2003). V poiskakh istiny (Searching for Truth, in Russian), Logicheskii analiz yazyka. Izbrannoe 19881995. Moscow: Indrik.

Gorelov, I.N., \& Sedov, K.F. (2005). Osnovy psikholingvistiki (Basics of Psycholinguistics, in Russian). Moscow: Labirint.

Laroshfuko, de F \& dr. (1990). Suzhdeniya $i$ aforizmy (Judgments and Aphorisms, in Russian). Moscow: Izd-vo politicheskoi literatury.

Pavlovskaya, A.V. (2006). Italiya i ital'yancy (Italy and Italians, in Russian). Moscow: Izd-vo Olma MediaGrupp. 
Sadokhin, A.P. (2010). Mezhkul'turnaya kommunikatsiya (Intercultural Communication, in Russian). Moscow: Al'fa M. INFRA - M.

Soon, A. (n.d.). How to give a good compliment. Retrieved from http://lifecoachesblog.com.

Wierzbicka, A. (1997). Yazyk. Kul'tura. Poznanie (Language. Culture. Cognition, in Russian). Moscow: Russkie slovari. 